KATALIN ESZTER MORGAN

\title{
RECLAIMING A DWELLING PLACE: HOW A GERMAN HISTORY LEARNING COMMUNITY HANDLES TRAUMATIC MEMORIES OF SHOAH WITNESSES
}

\begin{abstract}
This paper describes the results of an empirical study in which the objective was to find out how traumatic narratives by Shoah survivors are handled in a classroom setting. The study was conducted using an ethnographic approach by means of which a history lesson sequence was observed and analysed. The teaching medium of the lesson was a digitised presentation of memories by Shoah survivors. The description of the lesson establishes how teachers and students negotiate the difficult terrain of an emotional engagement with the testimonies. The findings are discussed by elaborating on the meaning of traumatic memories for the witnesses, and in turn by asking what it means to listen to the telling of such memories. Conclusions are drawn about the overall meaning of (history) education.
\end{abstract}

Keywords: Shoah; witnesses; testimony; history education; emotions; trauma; memory.

\section{Introduction: studying emotional processes in history education empirically}

In this paper I want to take a look at an ethnographic case study that sheds light on how some school pupils and a history teacher negotiate the difficult terrain of engaging with the topic of the Holocaust by using witness testimonies. Such witness testimonies were made available through a DVD medium called "Witnesses of Shoah-school learning with video-interviews". The educational materials on this DVD medium include video-recorded testimonies of Jewish and non-Jewish witnesses-mostly victims but also a few resistors-as well as literary sources in the form of extracts from memoirs and biographies. Perpetrator witnesses and bystander accounts are not included. The testimonies on the DVDs come from the Steven Spielberg Visual History Archive (VHA) housed at the Shoah Foundation of the University of Southern California. The DVD series also includes various tasks and assignments, for the solving of which additional materials are provided

1 Retrieved from http://www.zeugendershoah.de 
in the form of primary sources and other historical materials in multiple modes such as animations, images, graphs, maps, literary texts, poems, etc. This software package can be purchased by any teacher from the Federal Agency for Civic Education (Bundeszentrale für Politische Bildung). ${ }^{2}$

The focus of the case study is not so much on assessing whether using witness testimony helps pupils to get better at historical thinking, although the relationship between history learning and the witness' memories is a focus. More generally, I am looking at how the pupils interact with the testimonies, given that learning this history from the victims' perspective was a new experience for them, and observing this interaction was a new experience for me. The study presented here can shed some light on the kind of discourses circulating when teachers and pupils interact with the witness' testimonies who share their traumatic experiences. That these responses are to some extent staged, artificial and routinised as a result of the need to conform to certain school expectations and norms is a given. This social conformity and habitual effect cannot be eliminated in empirical studies based on observations and questioning. But this does not make the results worthless. The relevance of studying these interactions lies in contributing to a general understanding of the role emotions play in an educational landscape where emotional access to historical content has been viewed skeptically (see Morgan, 2018a). Therefore I shall consider emotions as an inevitably part of meaning-making and the focus will be on how this occurs. To a lesser extent I will also pay attention to moral issues as and if they become manifest. In the next section I describe the methodology employed for the study and then present and discuss the findings in the context of the research about the sharing of traumatic memories.

\section{Methodology}

The case study describes a setting in an ordinary state Gymnasium ${ }^{3}$ in a Nordrhein Westfalen (NRW) small town with about 36000 inhabitants and a population density of about 240 persons per $\mathrm{km}^{2}$. It has a homogenous population whose members, according to the teacher, are "all Catholic". The history class was predominantly, if not exclusively, composed of Germans without dual citizenship and the age of the learners ranged from 17 to 19 years. In total 23 pupils comprised the history class. The teacher had 15 years experience in teaching history and also music.

The data for the case study was collected using an ethnographic approach, which aims to describe what is happening in a particular setting, providing a holistic picture of how a particular social group operates (Church, 2010). It investigates the routine lives of people, using multiple methods, including interviewing,

2 Retrieved from http://bit.ly/fp2019-1-morgan1.

3 Among the four existing school types in Germany, this is the most academically orientated one, preparing learners for university study. 
observing, quantitative work such as surveys, and assembling cultural artefacts (Walford, 2008, p. 2). Ethnography considers human behaviour as symbolic action (culture) that can be understood by means of constructing a reading of that which is foreign (see Geertz, 1973, p. 10). This approach was chosen because I as the researcher was not familiar with this cultural setting. Ethnography is thus an "imaginative act" (ibid, p. 15) because it is inevitably entwined with personal experience, given that the thick descriptions involve the participant's (researcher's) perspectives on the events described (Church, 2010). Participant observation leads to a kind of "involved detachment" that calls for being open minded and allows for becoming aware of unanticipated details, arriving at a holistic study (Moeran, 2007). As such I did not have a particular agenda while observing the lessons and tried to take in as much of the totality of the situation as possible. The focus in this article is on emotionality, which is why the presented lesson sequence is described from a perspective that pays special attention to that aspect.

In the school where the study was conducted the teacher, Mr. Dumont ${ }^{4}$ used the DVD medium for six weeks during a total of sixteen 45-minute history lessons, fourteen of which I attended and observed as a researcher. The presented part of the study is based on observations and on an audio-recorded lesson sequence that was transcribed. In addition to the observations and the recording, I also conducted interviews with the teacher and with some pupils (who had agreed to participate in focus group discussions) after the project. Although data from these sources are not included here, they nevertheless influenced the way I interpreted the transcript (consciously and subconsciously), meaning that my interpretation is also partly based on evidence that I cannot reproduce here.

\section{The history lesson sequences}

At the beginning of the project (December 2015), Mr Dumont allowed each pupil to choose which interviews and tasks to work on. They listened to different interviews either on their own, or with a partner and answered the set questions on the learning software accompanying the interviews. This went on for eight lessons without any class interaction. I then proposed to the teacher to select certain tasks and thus to reduce not only the choices for the pupils, but also to create an interactive situation that could be observed. While the pupils were busy watching the interviews during one of the lessons, Mr. Dumont and I selected 15 of the 60 existing tasks. We did this quickly and spontaneously, guided by personal interests and the aim of taking all four themes ("fleeing,", "surviving", "resisting" and "continue living") into account. After the selection was made, Mr. Dumont asked each pupil or groups of up to three pupils to choose one task and to prepare a presentation on it to the class after the two-week Christmas break.

4 All names of persons and institutions were changed. 
In the first lesson of the new year, two pupils presented on what they had remembered from the interview with Lissi Pressl ${ }^{5}$, who had fled from Germany in 1936, but had returned after the war. They talked about the emotionally tragic parts of the story. These emotional references were Lissi's feelings of fear about having to go to another country on her own as a young woman and thus to lose contact with her close extended family; how horrible it must have been to experience crude exclusion by her classmates after Hitler "took over" power (her "friends" had stopped talking to her at school); that she had felt guilty for having left her family behind who was later murdered; how she was beaten up once; and that despite all she had experienced, she still considered Germany to be her home. One of the other learners in the class added what he remembered from the story and made corrections about some factual details. The teacher responded by saying that "if there are any factual mistakes in the retelling of Lissi's story, then you have to correct these."

He did not pay attention to the emotional references that the first group of pupils made to Lissi's story, but responded to their presentation with factual questions. For example, when one of the pupils talked about the part in Lissi's story in which she recounted the execution of her brother and mother with much pain (the mother was first forced to watch the execution of her son before the Nazis shot her too), the teacher responded by asking, "do you know where that was and when? Because it must have been about 1941 or ' 42 ." Thus the emotionality and the presence of the horror in Lissi Pressl's life were not talked about. The pupils also discussed the way Lissi Pressl told her story-her body language-as a response to the learner task which particularly emphasised the interrogation of this aspect of the interview. Here too the teacher did not offer any information about the connection between the content of the story and the way Lissi had told it. Instead, he asked the pupils to establish this connection. They did so by linking their observations of her body language to certain contents of her story. For example, they mentioned that when Lissi spoke about a particularly horrible experience, she looked down to the floor. Conversely, she smiled when she talked about pleasant memories of her family. No further interpretation of this aspect of a video-interview was discussed.

In the following lesson, a pupil presented the task on a literary text analysis. It was a text excerpt of Charlotte Delbo's memoirs of Auschwitz. The task was to summarise how Charlotte Delbo describes life with the memory of Auschwitz and then to discuss her final sentence with the help of individual statements in the text. Pupils were also asked to consider the question of whom the author is addressing. Here is a section from the beginning of the original text ${ }^{6}$ :

5 Zeugen der Shoah, DVD1: Fleeing.

6 The original is in French and the one with which the pupil worked is a German translation. The text here is an English translation thereof by the author. 
It is impossible that I did not also die. Everyone died. I have the impression of not being alive. [...] Everyone died. Mounette, Viva, Sylviane, Rosie, everyone else, everyone else. Those who were stronger and more determined than me died and I am supposed to be alive? Was it possible to get out of there alive? No. That was not possible. Mariette with her eyes like still water, her eyes that did not see, because this still water did not let her see death. Yvette [...]. No, it's impossible. I am not alive. I know it deep down inside from the depth of my loneliness. You, you understand what I want to say, what I feel. The people do not. How should they understand? They did not see what we saw. They did not count their dead every day at dawn [...]. We spent the days counting. We would have been afraid to count the living. And for every dead person we counted, there was neither grief, nor tears. A worn out pain. We were just fear and anxiety: how many more days before they would count me? [...] And this willpower, this craze to endure, to persevere, to carry on, to come out, to be the voice that would return and report, the voice that would draw up the final account (die Schlussabrechnung machen würde). [...] And at the same time an icy emptiness: why return if I am the only one to return? And now I am here, but also dead. (Zeugen der Shoah, DVD 2: Surviving)

The pupil interpreted the text in the following way:

Charlotte Delbo writes about how she had felt when she was deported to Auschwitz. She had very extreme feelings because she said that she feels as if she were dead, not alive, because she was surrounded by so many dead. [...] Right in the first sentence she says, 'I have the impression of not being alive. So many have died. It is impossible that I too did not die. Everyone is dead.' And then she lists a whole lot of names, that she somehow lost, well actually people with whom she had a personal relationship [...]. She had to somehow constantly count the dead that were lying around, without showing any emotions and they had to do it without really being allowed to show sorrow or grief. And she said that she thought a lot about ("extrem viele Gedanken gemacht") whether one would also be counted with the dead sometime and how all this would continue. And that's why she thought that she was also dead and she also said that if it were to continue like this, if she always had to count so many, that at some point all would be dead, and if she were the last one for example, she would be all alone and therefore it is as if she were not living anymore. [...] And that is quite extreme, if you look at it and consider, if you were in this situation, how, well, hopeless she felt and in what extreme terms it was described. So that the whole time she really had the impression that there would be no point, well she sorts of does not carry on living so to speak. And there you can only imagine how bad the situation must have been if one develops such an extremely terrible way of thinking. 
After this interpretation, Mr Dumont asked the pupil whether the author of this text was the same as the artist of the drawing "access block", the analysis of which the same pupil was going to present later. "No, no," said the pupil and continued as he remembered that one of the task questions was about the addressees, "I would imagine that she was addressing it to the next generation, to the continuing world, and to leave her thoughts behind and also a bit for herself as a way of dealing with the situation through writing about her emotions. Because many would perhaps be ashamed, in retrospect, to have had such thoughts."

The teacher wanted to find out more about the situation around Delbo's "work" of having to count the dead because he was not familiar with the text. The pupil was not sure either and took up the personal aspect of the testimony instead: "Everyone died. And then she lists all these names, all those, well that she actually lost only personal relationships." The teacher then shifted the focus to talk about a text that the class had discussed in a different lesson. It was a "perpetrator" text by Kurt Gerstein who reported from Bełżec about the situation for Jews in terms of having been granted the chance to stay alive if they carried out the worst jobs imaginable, like breaking out the teeth from the dead that had gold in it.

"If we have a person who had to experience something like that, you mentioned the feeling of being ashamed, and I would say the feeling of guilt could also become manifest, what do you say to that?" One pupil answered that for her the feelings of guilt had to do with having to do something that cannot be deemed normal work fit for humans and that the situation described by Delbo "is perverse, because you cannot really imagine that such a thing has taken place in real life. And I think that the description of feeling dead while still alive is a very good one for this situation." One pupil said, "well, I can imagine that one felt like a monster having to do work like that." "You said like a monster?", the teacher asked. "Yes."

Then the teacher continued: "Ok, so like someone who functions only as a machine and who totally blanks out his or her consciousness. Is this behaviour understandable? I always try to imagine myself in the situation, well I only try, I don't succeed." The pupil who originally presented his interpretation reminded the class that doing this horrible work was not a matter of choice for Delbo: after citing from her text, he said, "to me it sounds like she was forced to do it rather than as a compensation for being allowed to live." The teacher agreed that there was no choice really. One of the pupils said that she would have asked herself if she were rather dead than to have to live with this her whole life, even though she thought that Delbo, through the writing down of her story, must have found a way of dealing with it, "and I think in that moment, I don't know if this survival instinct would have kicked in or whether I would have rather wanted to die. Because in that camp she was in, this extreme situation that she still would not have known whether she came out alive. I don't know whether I would have then made the same decision."

This challenging discussion about life and death continued for about 20 minutes. At each difficult turn, the teacher said, "I don't know, I cannot judge." Coming 
back to the point of who the addressees were, one of the pupils surmised that the value in this testimony is the passing on of a message to the next generation, which is the preciousness of relationships with other people and how much you have to appreciate those in order to have some sense of joy in life:

That when you see something as terrible as she did, that's when you realise how valuable it is to have a family. I think the intention of the text was this because she wrote it completely from her own perspective. Although not addressing anyone specific, but you could still hear that in her text, or you automatically think about how valuable that actually is.

During the 20 minute discussion the pupils made numerous thought experiments in terms of trying to understand Charlotte Delbo's memoirs from her perspective. In this discussion human dignity was mentioned, and that life is not worth living "after such an experience, or at least directly afterwards." The teacher mentioned that when talking about losing and regaining dignity, then "it is already a philosophical, existential question." One of the pupils tried to imagine what it must be like to know that your "group of people" is being gassed and that therefore the fear of the way of dying is even greater, "and I can imagine that because of this, she preferred the counting of the dead. But after all, she admitted that imagining this was not really possible: "I find it really hard to imagine, because somehow it is not possible. And I think you can't even describe, I don't know how they have felt." To which the teacher replied, "you cannot put that into words. Well, maybe you can try, but whether the listener receives it in the same way, I can almost not imagine that". To him, the weight of the burden of having to live with an experience that so completely robbed the person of her dignity was unimaginable and very difficult to understand.

Mr Dumont tried to wrap up the discussion because he thought that it was going around in a bit of a circle. He summed it up as follows: "We can take from this the inexpressibility of the situation. And what I found very important was that, as you said, she tries to turn it to something positive. She wants to tell the readers by writing the book, if I have understood it correctly, that it is very, very valuable, to appreciate your fellow human beings, no matter whether you know them or not, and to be glad to be alive and to have people around you". One of the pupils took up a textual reference again and talked about the last bit of the Delbo text which was: "and this willpower, this craze to endure, to persevere, to carry on, to come out, to be the voice that would return and report, the voice that would draw up the final account (Schlussabrechnung)." He interpreted her message about the Schlussabrechnung (final account) as follows: "Well, it is as if she really had the wish to draw an end or a conclusion (einen Schlussstrich ziehen) by writing

7 Of course, with Charlotte Delbo it was not "her group of people" since she was not Jewish, but this point remained unnoticed and undiscussed in the lesson. It didn't really matter for the arguments developed in the lesson because Delbo indeed assumed the Jewish condition by having been subjected to the same trauma as those who were from the "Jewish group of people." 
about it. But still, in the end, well she is here but also dead. It is so to speak a good way of showing the attitude right at the end." The teacher responded that "up until now no one has mentioned this aspect of loneliness. Because to be the only one who has experienced this and you cannot talk about it to anyone who really understands it. I believe this is an additional burden, which is also unimaginable. A very difficult topic. Perhaps it was a bit too high a hurdle to start with such a text. Oh well, sometimes you cannot choose, right?"

\section{Discussion}

Although the selected lesson sequence is a tiny sample of the data I gathered in the field as a whole, it can nevertheless highlight a few pertinent issues. Of course the data is not representative and I do not claim generalisability. But by highlighting and zooming in on some aspects of the above interaction, some theoretical points become visible and manifest in a segment of reality. Based on this segment, the aim of this discussion is to deepen our understanding of the role of memory in historical learning about this difficult subject matter and thus to try and arrive at some conclusions about what this means for education (systems) more generally.

Lawrence Langer points out that there are several currents that flow at different depths of a Holocaust testimony and that our understanding of the event depends on the source and destination of the current we pursue (Langer, 1991, p. xi). Based on the observation and recording of the lesson sequence, the source and destination of this pursuit, although influenced by the task questions to some degree, was not premeditated by the teacher or by any "emotionalising" agenda. ${ }^{8}$ Neither could I detect any evaluative processes that were driven by a curricular script or a competency-based model of education or instruction. Instead, what I found were highly skilled, literate and articulate youngsters who, together with their teacher and with each other became equal partners in negotiating answers to existential questions; the answers to which they simply did not know and at times did not even begin to be able to imagine, although they really tried. Thus, in this example, the school setting could not be identified as "social control" (Boler 1999, p. 33) and the testimonies were not used in a moralising way ("you shall know!"). A "choreography of emotions" in the sense of an expectation of emotionally initiated processes of empathy generation (Heyl, 2013) or an expectation to acquire certain unfamiliar norms (Greve, 2014, p. 188) were not observed.

In order to make sense of how this history learning community handled the traumatic memories of Shoah witnesses, let us recapture that one of the key mandates of history education in Germany is to keep the memory of the Holocaust victims alive (Meseth \& Proske, 2010, p. 202). But what does that mean exactly?

8 "Emotionalising" in German history education discourse usually refers to the expectation to feel a sense of guilt or remorse when interacting with witness accounts. 
To find out, we should first ask what traumatic memory and the testifying to it means for the survivors. And then we can ask how this meaning in turn contributes to the meaning-making patterns of the history learning community under study. What became clear from the data is that history learning was too narrow a disciplinary space for handling the traumatic memories. Weighing up evidence and assessing factual data did come up in the beginning when Mr Dumont and one of the other pupils insisted on factual accuracy during the interpretation of Lissi Pressl's testimony. But it soon became apparent that focusing on such details did not add to the meaning of the story because she was not testifying simply to historical empirical facts, but like other victims, "to the very secret of survival and of resistance to extermination" (Laub, 1992, p. 62). As Mr Dumont said, what the witnesses shared opened up a "very difficult topic", involving a philosophical, existential question.

Although he did not know how to respond to the emotional parts of Lissi's story and thus reverted to the apparently safe and familiar pattern of asking factual questions, he soon realised that working with victim testimony demanded a widening of the space called history learning. This space, in its narrow sense, is the learning about the past in a factual way through discursively organised knowledge that relies heavily on dates and names of past events (as these are verifiable). It was also apparent that Mr Dumont may have been a little underprepared for the lesson, given that he was not familiar with Delbo's text or the stories of the other witnesses. But as Laub (1992, p. 61) notes, when listening to traumatic memories, it is sometimes useful to not know too much about the historical facts surrounding them, because this might drive one's own agenda of confirming or rejecting the content of what is said, leading to an inability to learn new, diverging and unexpected information. To be open to such new insights, it is helpful to bear in mind that traumatic testimonies "allows for truths to emerge from a plane on which testimonial reference cannot be recognised and adjudicated as discursively organised knowledge" (Simon \& Eppert, 1997, p. 182). ${ }^{9}$ Thus the teacher's lack of knowledge (not ignorance!) was an asset in disguise because it allowed him and his pupils to venture into the extended territory of psychology and philosophy and with it to discover new, unexpected insights. He realised that his familiarity with the methods of history was not enough for dealing with testimony, because truth from this perspective is not understood as evidence but rather as trauma (Eppert, 2002, p. 88). So let us take a look at trauma and traumatic memories, which are the bridging concepts between history and the terrains that are more concerned with existential issues.

Memory in general in its neurological, social and communicative nature has been studied extensively. One of the conclusions is that the "texture" of memory is so complex and so ephemeral that it is more accessible to artists and literary writers

9 This conclusion is based on Simon and Eppert's (1997) reference to Laub's analysis of the differences between how some historians and a psychologist like himself evaluate witness testimony. 
than to scientists (Welzer, 2001, p. 11). Traumatic memories add another layer of complexity. One way to think about them is to distinguish between "common memory" and "deep memory". Referring to Charlotte Delbo's work, Langer (2006, p. 305) explains that common memory is intellectual memory, which is connected with the thinking processes, and deep memory is the memory of the senses. "Deep memory tries to recall the Auschwitz self as it was then" and common memory "offers detached portraits, from the vantage point of today, of what it must have been like then." (Langer, 1991, pp. 5-6) Phrases like "trying to recall" and "being detached" from the event point to its traumatic nature, which is characterised by a dimension that is beyond time and space, and beyond the memory and comprehension of the witness himself or herself: "The trauma survivor who is bearing witness has no prior knowledge, no comprehension and no memory of what happened. [He or she] profoundly fears such knowledge, shrinks away from it and is apt to close off at any moment when facing it. [...] Such knowledge dissolves all barriers, breaks all boundaries of time and space, of self and subjectivity." (Laub, 1992, p. 58)

This difficulty with traumatic memory was evident from the responses to Delbo's testimony. Both pupils and the teacher tried very hard to imagine (access emotionally) what it must have been like for her and they searched intently for the appropriate words to describe intellectually what she must have gone though. But Delbo's experience remained elusive to them. This was shown through responses such as "I find it really hard to imagine, because somehow it is not possible", or "you cannot put that into words." Both the teacher and the pupils struggled to make a connection between the witnesses' account and their internalisation thereof by means of language. We need to bear in mind that the pupils had been listening to and watching other video-testimonies on the DVDs for eight lessons prior to this lesson either on their own or with a partner and with no "interference" from $\mathrm{Mr}$ Dumont. As such, they would have been sensitised to the expression of trauma of the witnesses through the body language. This aspect was meant to be critically examined by the learning community according to the designers of the DVDs. But this aspect also came too short, because trauma lies outside of our emotional and intellectual grasp (Eppert, 2002, p. 87). It cannot be explained.

However, this does not mean that the teacher and the pupils did not fulfil their roles as listeners. Given that massive trauma precludes its registration as a result of the temporary malfunctioning of the human mind during such events, the trauma as a known event has not been truly witnessed yet (Laub, 1992, p. 57). Testimony about traumatic events have not settled into understanding or remembrance and cannot be constructed as knowledge or assimilated into full cognition because they are in excess of our frames of reference (Felman, 1992, p. 5). Thus the narrator herself does not know who she was except through the testimony (ibid, p. 51). This self-knowledge can only happen through the testimony itself, i.e., it is neither a given before the testimony, nor is it a residual substantial knowledge 
after it. This means that "it can never become a substance that can be possessed by either speaker or listener" (ibid), which makes the role of the listener inextricably tied to the role of the speaker and "the listener therefore is a party to the creation of knowledge de novo. The testimony to the trauma thus includes its hearer, who is, so to speak, the blank screen on which the event comes to be inscribed for the first time." (Laub, 1992, p. 57)

If trauma cannot be grasped intellectually or emotionally, then what is left? I argue that the encounter between a witness and a Shoah victim must be understood on a spiritual level that subsumes both the intellect and the emotions. In addition, this cannot be divorced from the intentions behind the Nazi crimes which must also be understood spiritually in terms of its evil. Just like the listener of the testimony is inextricably tied to the teller through his or her co-construction of "truth", so is the teller tied to the event about which he or she testifies. If the event is to be "inscribed" on the listener, then this inscription signifies something that connects the event with the listener. To figure out what this signification is, we have to ask what the Nazis' intention was in their attempted obliteration of Jewish existence. I argue that it was a spiritual intention, not just a historical war. Patterson (2006) shows in great detail, based on witness testimonies and theological insight that what the Nazis contrived in their obliteration of the life of the Jewish people was the obliteration of The Name (haShem or the God of Israel) as the origin of their name and their memory and with it their existence as a whole because remembering is seen to be determinative and constitutive of Jewish existence and identity as seen in terms of origin and destiny (see Assmann, 1991; Yerushalmi, 1982, p. 9; Greve, 2014). To show how the Nazi assault was a war against memory, Patterson (2006, p. 201) quotes an example from Spielberg's Schindler's List in which Amon Göth addresses his troops just prior to the liquidation of the Krakow ghetto: "The Jews have lived in Krakow for six hundred years. By the end of the afternoon, those six hundred years will be a rumour."

If the Nazi intention behind their crimes was to obliterate the existence of the Jewish people by erasing their memory, then when a Shoah survivor testifies, he or she is reclaiming this assault on that memory. He or she does this by reclaiming a home, both physical (by inscription) and metaphysical (by reconnecting to Father by means of a name). It is an endeavour of "creating (recreating) an address, specifically for a historical experience which annihilated the very possibility of address." (Felman, 1992, p. 41, italics in original) Here "address" refers to both a physical home and a calling someone by name. When the pupil in the lesson sequence highlighted Delbo's listing of those individual names and thus assumed that she must have had a personal relationship with them, he was realising a profound insight, albeit one that is not measured by any "competencies" of historical learning. A name, from a spiritual perspective, gives a soul its life and humanity." (Patterson, 2006, p. xii) If the listener to the testimony is a co-constructor of the "truth" of the event to which the witness is testifying, then 
the pupil by implication was an instrumental part in giving Delbo back some of her humanity and her life. For a spiritual understanding of this process, an alternative understanding of time-and with it historical consciousness-is required.

The emotional reception of the survivors' stories and a focus on close relationships allowed pupils to gain this new type of historical consciousness. For example, the first group of presenting pupils interpreted Lissi's story by means of stressing her family relationships and the emotionally traumatic parts, such as knowing that her mother and brother were murdered in cold blood. Another pupil kept repeating Charlotte's "extreme feelings" regarding her ordeal. When a narrative is established by means of emotional relationships, then the temporal orientation across past, present and future is not a linear one but one that "recognises death while resisting the dissolution that is death." (Simon, 2000, p. 11) This dissolution refers to "timelessness" that is characteristic of trauma, an event that does not end (Laub, 1992, p. 67). What the listening to the testimonies of the survivors achieves then, is to affirm, via accessing the timeless (spiritual) dimension, the survivor's ongoing identity (a name) by providing a home or a dwelling place for her memory. To be willing to listen to and appropriate survivors' traumatic memories, we are in fact providing "a psychic locus for the foreclosed wounds of the past" or a psychic residence for those memories." (Silvermann, 1996, p. 185) The function of Holocaust memory then is to make it possible to find a dwelling place in the world (Patterson, 2006, pp. 209-215) and by being listeners and providing this dwelling place, we tend to an affirmation of the sanctity of human life.

At the end of the history lesson, Mr Dumont highlighted this aspect by drawing attention to the sanctity of human life. He stressed the value of appreciating our fellow human beings, based on their humanity and not on their similarity to "us". From a spiritual or ethical perspective, "the self is not constituted by self-reflection, nor through the accumulation of sensible experience and rational abstraction. The self is first of all in relation to other people." (Levinas quoted in Eppert, 2002, p. 96) It is this communicating with others that returns meaning to the world (Patterson, 2006, p. 206). Thus it is not about being tolerant towards other races, sexes, classes, religions, etc. and bringing these into relation to one's own individualised and localised self. Such would be a common interpretation of the history curriculum's focus on "self-reflection" and "self-competence" (even though the terms leave much to the imagination, see Wein et al., 2009, p. 14) or other systematically gradable, mostly cognitive learning performances. If recognising and appreciating the sanctity of all human beings was the only outcome of having engaged with the witnesses' testimonies, then a valuable educational goal would have been reached because the distinction between self and other that situates the self or reader unproblematically as judge (Boler, 1997, p. 258) would have been diminished. The situating of the self in relation to the other is what Fremdverstehen (understanding of "alterity") is about. As established earlier, the process of testimonial reading requires a "self-reflecting participation" whereby 
the reader "accepts responsibility as a co-producer of truth." (ibid, p. 263) This way, just by engaging with the testimonies over a relatively long period of time, as the pupils did over eight lessons prior to the presented lesson sequence, the history curricular aim of "self-reflection" or "self-competence" may have been realised in a positive way that is not based on the principle of ego-centrism. Ego-centrism is the principle on which most of liberal-humanistic and progressive processes are based. They stress the difference between self and other rather than viewing them as one (Eppert, 2002, p. 79, see also Morat, 2008, p. 111). A non liberal-progressive selfunderstanding would recognise "our humanity in the person of historical actors" (Seixas \& Peck 2004, p. 113), as the Canadian history curriculum emphasises, and as such would not regard that person as "the other". This way the liberal-progressive principles underlying a democratically constituted society might be reflected and maybe even "mastered" (bewältigt). ${ }^{10}$

But if we are not called to be judges as Boler argues, then what are we to make of history education's call for Urteilskompetenz (judging competence) in terms of the traumatic memories that require some kind of moral judgement? Proske (2009, p. 45) mentions that when we talk about morality in history lessons, then it usually implies a limited form, namely as learned methodical-cognitive competencies in order to be able to make historical value judgments in an argumentative manner. This type of Urteilskompetenz was manifest in one of the pupil's interpretation of Delbo's reference to the Schlussabrechnung (drawing up the final account). He made an apparent rational judgement by assuming that she wanted to put the whole experience behind her (einen Schlussstrich ziehen) and make peace with it through writing it down, and also possibly to deal with her sense of (perceived) survivor guilt (which came up more than once in the lesson sequence). This judgement was apparently rational by the word-connection "Schluss" that is not that apparent in the present English translation. In order to understand what is going on here, some discourse analysis is necessary. "Einen Schlussstrich ziehen" means to want to be done with a matter - to "rule off" on a page so to speak. Within the specific Holocaust discourse it expresses a desire to stop having to "deal with" the Shoah after all these years. Some see it as a condition for reconciliation because they do not want to be "burdened" by the guilt of their forefathers (see interview data collected for a study on antisemitism by Scherr \& Schäuble, 2007 for example).

Charlotte Delbo used another word though. She wrote (in the German translation of the French original) "Schlussabrechnung". The two have different if not opposite meanings. A "final account" suggests that something is owed. Somebody owes something to someone. The author's voice serves as a reminder that the accounts are not settled. But the hope for payment is futile considering the fact that the witness is

10 We need to ask here what liberty and freedom mean. For some thinkers true liberty does not mean the freedom of individual autonomy or willpower. On the contrary, "freedom is the liberation from the tyranny of the self-centred ego." (Heschel, 1955, Kindle location 249) 
the only one to submit the account. Even if the "money" (compensation, an apology, expressed regret or remorse perhaps) were paid, it would still be pointless, given that all the victims are dead. But the pupil-and those who talked about survivor guilt or that the victim is "ashamed" or feels like "monster"-interpreted this as if Delbo herself would have to pay for it by "letting go" of the past or by choosing to forget about it, or that she would cancel the debt because she has learnt to "deal with it" through her writing it down. But, as we saw earlier, the trauma does not end. So this interpretation is wishful thinking and can be seen as an attempt to absolve oneself from possible guilt - a good example of an Entlastungsstrategie, which refers to processes of or a desire for literally un-burdening oneself either from guilt, or from responsibility, or both (see Wein et al., 2009). It shows that it was not a case of making a purely rational judgement because the desire to not have to account for this history (anymore) was commingled with the factual judgement, leading to an error of interpretation.

Mr Dumont did not register this mistake. Rather, he saw it as an added problem to the inability to speak about emotionally weighty matters, in this case about the total aloneness in the world after an experience such as Delbo's. Knowingly or not, he thus encouraged the pupil's Entlastungsstrategie, also in terms of the timing. The pupil said it by way of a conclusion to the lesson and thus it could be interpreted as an attempt to conclude the matter. Mr Dumont supported it by concluding the lesson in real time. Perpetrator guilt was not discussed at all, only references to survivor guilt were made, a concept that is contested in the academic literature (see Juni, 2016) but was not done so in the classroom. ${ }^{11}$ This example shows how using Holocaust memory in German history lessons at some point tends to get entangled with notions of guilt and responsibility. Perhaps Urteilskompetenz requires special attention in history lessons, especially when it includes the "learning to reason in a nuanced manner about guilt and responsibility of Germans for the National Socialist crimes", as some curricula do (Alavi, 2013, p. 85). There are moral currents underneath the pretence of pure rationality, and they are not likely to go away.

\section{Conclusion}

If a number of German history curricula aim to teach learners to "take hold of", "grasp", "realise", or "get a sense of" the inhumanity and the barbarity of the industrially organised genocide, then, as this language use of the curriculum itself suggests, the narrow space of history learning that is discursively organised must be increased to include other ways of knowing. In this process emotions can serve

11 Juni (2016, p. 323) challenges the assumption that there is such a thing as survivor guilt at all, arguing that "guilt without culpability has the potential of reframing victims as perpetrators by mis-attributing negative consequences of an event to the very victims who were merely hapless pawns in a tragedy." 
an important function in connecting the primary witness with the tertiary one. As such, emotions are not necessarily abused or manipulated for any sinister motives, as this case study has shown. Neither did they lead to any cognitive impairment. On the contrary, the learning community talked about the testimonies in very articulate, reflective ways, leading at times to profound insights that did not seem as such at first glance. But if the mandate is not only to grasp inhumanity but also to counter it, then its becoming must be understood. This goes beyond rationally countable facts and even an emotional experience of listening to the witnesses' pain. To understand the becoming of inhumanity is to understand evil and for this, spiritual insight is needed into the intentions underlying the crimes of the Shoah (see Confino, 2014). Based on insight about the specificity of the Nazi crimes, the function of witnessing to traumatic testimony can be realised.

This function is that of allowing the reclaiming of a dwelling place for the lifeconstituting memory of the victims that was intended for total obliteration. This requires a risky willingness because "trauma leaves no hiding place" (Laub, 1992, p. 72) for the listener. The telling of traumatic memories entails a reclaiming of the assault on memory and constitutes a "re-externalisation of the evil that affected and contaminated the trauma victim." (ibid, p. 69) The listener therefore is a part-taker of this evil temporarily. It is not a matter of rationalising or explaining and it's also not about a fleeting emotion of pity for the victim. Rather, it is an all-encompassing self-experience for which there are no words. ${ }^{12}$ The history curriculum's call for "self-reflection" and "self-competence" could be applied in this self-sacrificing sense, instead of the liberal-progressive way that is more common. The self-sacrificial way that is prepared to take on the trauma would lead to more of an existential education that rejects a language common in educational systems that tend to propagate the "omnipresence of anxiety and despair, resignation and indifference in the face of a seemingly already sold-out and betrayed future." (Greve, 2014, p. 204) Such conceptions undergird the pursuit of educational goals that are designed for keeping a system functioning smoothly. In such a system what counts are testability and an instrumentalisation of history learning towards an output-orientation as mere economic resources (Schulze-Wessel, 2016) and not the humanisation of children. Or, more poignantly, the school becomes nothing more "than a repository where skills and information are disseminated with the aim of imparting to students a greater power for plundering the world of its goods." (Patterson, 2005, p. 160) Using virtual testimony in history lessons could be a countering force.

While on the basis of the case study no claim can be made that such humanising took place, the subsequent interviews with the pupils nevertheless indicated this

12 See Felman, 1992 on how her students had to experience the evil inherent in the trauma of the virtual witnesses in order for the interaction between them and the students to have become a meaningful educational exercise. 
sense to an extent. Many of them were shocked and horrified by what they had seen and heard and understood perhaps for the first time that it was "not hundreds of thousands, but one, plus one, plus one, plus one." (see Morgan, 2018b) Still, the data presented here did show in a rudimentary way that in order to achieve the humanising goals of history education, the teacher had to leave the narrow space of history teaching to deal with the traumatic memories of the witnesses. Whether from lack of expertise knowledge in psychology, philosophy or theology, or whether he was underprepared for the lessons, he treated his class-time as an opportunity for his students to grapple with difficult existential questions, the answers to which he did not have. He refrained from making definite judgements or sharing too much of his own interpretations. This led to a situation whereby his pupils spontaneously provided a dwelling place for the memories of the witnesses and thus affirmed the latter's name and identity. It was not a matter of asking "what can we learn from the memories of others?", but rather "what might it mean to remember other people's memories?" (Simon 2000, p. 10) Perhaps this is an appropriate question for guiding the work with traumatic witnesses' memories in history lessons.

\section{References}

Alavi, B. (2013). Herausforderungen an eine 'Erziehung nach Auschwitz' in der multikulturellen Gesellschaft. In H.-F. Rathenow, B. Wenzel, N.H. Weber (Eds.). Handbuch Nationalsozialismus und Holocaust (pp. 79-94). Schwalbach am Taunus.

Assmann, J. (1991). Die Katastrophe des Vergessens. Das Deuteronomium als Paradigma kultureller Mnemotechnik. In A. Assmann \& D. Harth (Eds.). Mnemosyne. Formen und Funktionen der kulturellen Erinnerung (pp. 337-355). Frankfurt a.M.: Fischer Wissenschaft.

Boler, M. (1997). The risks of empathy: Interrogating multiculturalism's gaze. Cultural Studies, 11(2), 253-273.

Boler, M. (1999). Feeling Power. Emotions and Education. New York: Routledge.

Church, J. (2010). Ethnographic approaches to education research. Retrieved from http://bit.ly/fp2o19-1-morgan2.

Confino, A. (2014). A World Without Jews. The Nazi Imagination from Persecution to Genocide. Yale: Yale University Press.

Eppert, C. (2002). Entertaining History: (Un)heroic Identifications, Apt Pupils, and an Ethical Imagination. New German Critique, 86, 71-101.

Felman, Sh. (1992). Education and Crisis, Or the Vicissitudes of Teaching. In S. Felman \& D. Laub (Eds.). Testimony: Crises of Witnessing in Literature, Psychoanalysis, and History (pp. 1-56). New York: Routledge.

Geertz, C. (1973). The Interpretation of Cultures. Selected Essays. New York: Basic Books Inc. Publishers. 
Greve, A. (2014). Zachor - Erinnern lernen. Aktuelle Entdeckungen in der jüdischen Kultur des Erinnerns. Berlin: epubli GmbH.

Heschel, A. J. (1955). The Insecurity of Freedom: Essays in Human Existence. New York: Farrar, Straus and Giroux (Kindle Edition)

Heyl, M. (2013). Mit Überwältigendem überwältigen? Emotionen in KZ Gedenkstätten. In J. Brauer \& M. Lücke (Eds.). Emotionen, Geschichte und historisches Lernen. Geschichtsdidaktische und geschichtskulturelle Perspektiven (pp. 239-259). Göttingen: V\&R Unipress.

Juni, S. (2016). Survivor guilt: A critical review from the lens of the Holocaust. International Review of Victimology, 22(3), 321-337.

Langer, L. (1991). Holocaust Testimonies: The Ruins of Memory. Connecticut: Yale University Press

Langer, L. (2006). Hearing the Holocaust. Poetics Today, 27, 297-309.

Laub, D. (1992). Bearing Witness or the Vicissitudes of Listening. In S. Felman \& D. Laub (Eds.). Testimony: Crises of Witnessing in Literature, Psychoanalysis, and History (pp. 57-74). New York: Routledge.

Meseth, W., Proske, M. (2010). Mind the Gap: Holocaust education in Germany, between pedagogical intentions and classroom interactions. Prospects, 40, 201-222.

Moeran, B. (2007). From Participant Observation to Observant Participation: Anthropology, Fieldwork and Organizational Ethnography. Creative Encounters. Retrieved from http://bit.ly/fp2019-1-morgan5.

Morat, D. (2008). Verstehen als Gefühlsmethode. Zu Wilhelm Diltheys hermeneutischer Grundlegung der Geisteswissenschaften. In D. Morat \& U. Jensen (Eds.). Rationalisierungen des Gefühls. Zum Verhältnis von Wissenschaft und Emotionen 1880-1930 (pp. 101-117). München: Wilhelm Fink Verlag.

Morgan, K, (2018a). How do traumatic Shoah-witness testimonies fit into German History Education? Forum Pedagogiczne, 1, 273-285. Doi: http://dx.doi. org/10.21697/fp.2018.1.18

Morgan, K. (2018b). 'It was not hundreds of thousands, but one, plus one, plus one, plus one' - emotions and empathy in history learning with Shoah survivors. Testimony - Between History and Memory, 126, 102-111.

Patterson, D. (2005). Hebrew Language and Jewish Thought. New York: Routledge Curzon.

Patterson, D. (2006). Wresting with the Angel. Towards a Jewish Understanding of the Nazi Assault on the Name. St Paul, MN: Paragon House.

Proske, M. (2009). Moralerziehung im Geschichtsunterricht. Zwischen expliziter Vermeidung und impliziter Unvermeidlichkeit. In J. Hodel \& B. Ziegler (Eds.). Forschungswerkstatt Geschichtsdidaktik (pp. 44-53). Bern: h.e.p Verlag.

Scherr, A., \& Schäuble, B. (2007). 'Ich habe nichts gegen Juden, aber...' Ausgangsbedingungen und Perspektiven gesellschaftspolitischer Bildungsarbeit gegen Antisemitismus. Berlin: Amadeu Antonio Stiftung. Retrieved from http:// bit.ly/fp2019-1-morgan4. 
Schulze-Wessel, M. (2016, September). Wie die Zeit aus der Geschichte verschwindet. Frankfurter Allgemeine Zeitung. Feuilleton, 25.09.2016. Retrieved from http:// bit.ly/fp2o19-1-morgan3.

Seixas, P., \& Peck, C. (2004). Teaching Historical thinking. In A. Sears, \& I. Wright (Eds.). Challenges and Prospects for Canadian Social Studies (pp. 109-117). Vancouver: Pacific Educational Press.

Silvermann, K. (1996). The Threshold of the Visible World. London and New York: Routledge.

Simon, R.I. (2000). The Paradoxical Practice of Zakhor: Memories of 'What Has Never Been My Fault or My Deed'. In I.S. Roger, S. Rosenberg, \& C. Eppert (Eds.). Between Hope and Despair: Pedagogy and the Remembrance of Historical Trauma (pp. 9-25). Lanham, Maryland: Rowman \& Littlefield.

Simon, R.I., \& Eppert, C. (1997). Remembering Obligation: Pedagogy and the Witnessing of Testimony of Historical Trauma. Canadian Society for the Study of Education, 22(2), 175-191.

Walford, G. (2008). How to do Educational Ethnography, London: The Tufnell Press. Wein, D., Brauer, J., \& Barricelli, M. (2009). Zeugen der Shoah: Historisches Lernen mit lebensgeschichtlichen Videointerviews. Das Visual History Archive des Shoah Foundation Institute in der schulischen Bildung. Medaon, 3. Retrieved from http://www.medaon.de/pdf/B_Barricelli-Brauer-Wein-5-2009.pdf.

Welzer, H. (Ed.) (2001). Das Soziale Gedächtnis. Geschichte, Erinnerung, Tradierung. Hamburg: Hamburger Edition.

Yerushalmi, Y.H. (1982). Zakhor. Jewish History and Jewish Memory. Seattle and London: University of Washington Press.

\section{ODZYSKAĆ NALEŻNE MIEJSCE - W JAKI SPOSÓB W NIEMIECKIEJ SZKOLE ODCZYTUJE SIE TRAUMATYCZNE WSPOMNIENIA OCALAEYCH Z HOLOKAUSTU}

Streszczenie: Artykuł przedstawia wyniki badań empirycznych, których celem było ustalanie, jak uczniowie i nauczyciele radzą sobie z traumatycznymi opowieściami osób, które przeżyły Holokaust. Badanie przeprowadzono w placówkach szkolnych w Niemczech, wykorzystując metodę obserwacji i analizy etnograficznej. Jako pomoc dydaktyczną wykorzystano cyfrową prezentację przedstawiającą wspomnienia świadków Holokaustu. Opisano sposób, w jaki nauczyciele i uczniowie radzą sobie w trudnej sytuacji emocjonalnego zaangażowania $\mathrm{w}$ przedstawiane świadectwa. Wyniki badań opracowano w formie rozprawy na temat znaczenia traumatycznych wspomnień świadków i umiejętności słuchania takich wspomnień. W podsumowaniu w sposób całościowy omówiono znaczenie edukacji historycznej. 
Słowa kluczowe: Holokaust; świadek; świadectwo; nauczanie historii; emocje; trauma; pamięć.

Katalin Eszter Morgan studied Sociology and Education in Johannesburg (South Africa), focusing on Social Science, History and Technology. Her PhD thesis completed in 2011 examined the representation of Nazism and the Holocaust in South African high school history textbooks. The publications from this work centered around issues of race, racism, stereotypes, as well as on theoretical issues pertaining to textbook analysis more generally. In 2015 she relocated to Germany, her former childhood home, to pursue an Alexander von Humboldt-funded post-doctoral study on the use of digitised, video-graphed Shoah victim testimonies. She is currently working on several papers documenting the results of this study, based at the University Duisburg-Essen. She is also working on a book project that draws on her personal biography to illuminate her experiences in the field. Her other research interests include Antisemitism, inherited or generational guilt and trauma, learning technology and media design, philosophy of history, and theories of memory. E-mail-Address: katalin.morgan@uni-due.de 